\title{
Décima: De la noche de los feos de Mario Benedetti
}

Allan Vargas Carranza

Si surgen lágrimas de pena de nuestros ojos maltratados copiosas mojen los candados o que se oxiden las cadenas y que se metan por mis venas las caricias que propinas en la piel de gelatina de esta horrible cicatriz mientras me besas la nariz con tus labios de piel fina

Eterna sea la noche entre tus brazos mañana las heridas no estarán você é linda sim dice un poema lo canto para ti mi libertad

Siento más sin antifaces los que la gente acostumbra ponerse siempre en la penumbra van pensando que así nacen olvidan que son disfraces que en los cines son engaños como las tendencias del año compradas siempre sin pensar para los lindos que al andar en los pies no se hagan daño
Eterna sea la noche entre tus brazos mañana las heridas no estarán você é linda sim dice un poema lo canto para ti mi libertad

Tus bellos ojos de emoción van aceptando nuestras gracias y desechando viejos días voy inventando una canción sonora desde el corazón estoy versado nuestros sueños volando como pájaros vamos contra la corriente de la mano entre la gente con el sol en nuestros rostros

Eterna sea la noche entre tus brazos mañana las heridas no estarán você é linda sim dice un poema lo canto para ti mi libertad

Eterna sea la noche entre tus brazos" 
